\title{
Reasons and implications of retracted articles in Brazil
}

\section{Razões e implicações de artigos retratados no Brasil}

\author{
Karen SANTOS-D'AMORIM' ${ }^{1}$ (D) 0000-0002-2043-3853 \\ Anna Elizabeth Galvão Coutinho CORREIA' (D) 0000-0002-6967-0550 \\ Májory Karoline Fernandes de Oliveira MIRANDA ${ }^{1}$ (D) 0000-0003-3523-7756 \\ Petrus SANTA-CRUZ2 (D) 0000-0003-2475-7764
}

\begin{abstract}
Over the years, cases of retractions due to unintentional errors or research misconduct have been the subject of discussion, being indispensable to avoid the propagation of misleading information. To understand this matter in the Brazilian scenario, this study characterizes the retractions of authorship or co-authorship of Brazilian researchers between 2002 and 2019, their related consequences and impacts on scientific activity. With a data collection performed at the Retraction Watch database, we analyzed quantitative aspects of the reasons for retractions, stratification by areas of knowledge, the time between publication and retraction, the association of journals and impact factor, authors'recidivism, the institutional collaboration between Brazilian institutions and countries and funding sources. The results of the analysis of 162 retractions indicate the prevalence of plagiarism (12.2\%), the incidence of retracted articles in the Bioscience area (28.1\%), in journals with Impact Factors between 2 and 5 (38.0\%), and with 2 to 4 authors (38.8\%). The occurrences and recurrences of retractions due to misconduct have an impact not only the author's professional activity but science. Thus, this article emphasizes the importance of prompt retraction, as well as of the need to improve mechanisms to prevent these articles from being published from the start.
\end{abstract}

Keywords: Retracted articles. Research misconduct. Research Integrity. Scholarly communication.

\section{Resumo}

Ao longo dos anos, retratações decorrentes de erros não-intencionais ou de má conduta na pesquisa científica têm sido objeto de discussão, sendo indispensáveis para evitar a propagação de informações errôneas. Para compreender como se configuram os artigos retratados no cenário brasileiro, este estudo caracteriza as retratações de autoria ou coautoria de pesquisadores brasileiros entre 2002 e 2019 relacionando-as às consequências e impactos na atividade científica. A partir de levantamento feito na base Retraction Watch, foram analisados aspectos quantitativos sobre as razões das retratações, estratificação por áreas do conhecimento, tempo entre publicação e retratação, associação entre periódicos e fator de impacto, reincidência de pesquisadores, colaboração institucional entre

\footnotetext{
1 Universidade Federal de Pernambuco, Centro de Artes e Comunicação, Departamento de Ciência da Informação. Av. da Arquitetura, s/n., Cidade Universitária, 50740-550, Recife, PE, Brasil. Correspondência para/Correspondence to: A. E. G. C. CORREIA. E-mail: <anna.correia@ufpe.br>.

2 Universidade Federal de Pernambuco, Centro de Ciências Exatas e da Natureza, Departamento de Química Fundamental. Recife, PE, Brasil.

Apoio/Support: Coordenação de Aperfeiçoamento de Pessoal de Nível Superior (Financing Code 001), Conselho Nacional de Desenvolvimento Científico e Tecnológico (Process nº 308070/2020-8) e Universidade Federal de Pernambuco (Manuscript Translation Announcement n 05/2020).

Article based on the master's dissertation of K. SANTOS-D'AMORIM, entitled "Do publicar ou perecer" às retratações e despublicações: consequências e impactos na ciência". Universidade Federal de Pernambuco, Recife, 2020.

Received on January 21, 2021, final version resubmitted on August 17, 2021 and approved on September 16, 2021.
}

Como citar este artigo/How to cite this article

Santos-d'Amorim, K. et al. Reasons and implications of retracted articles in Brazil. Transinformação. v. 33, e210001, 2021. https://doi.org/10.1590/2318$0889202133 \mathrm{e} 210001$ 
instituições brasileiras e outros países e fontes de financiamento. Dos resultados obtidos a partir da análise das 162 retratações, nota-se a prevalência de plágio (12,2\%), de retratações de artigos na área de Biociências (28,1\%), incidência de periódicos com Fator de Impacto entre 2 e 5 (38,0\%) e de equipes de autoria compostas por dois a quatro autores (38,8\%). As ocorrências e reincidências de retratações por má conduta trazem impactos na atividade profissional do autor e para a ciência. Assim, ressalta-se a importância da rápida retratação, mas também da necessidade de se aprimorar mecanismos para evitar que esses artigos sejam, desde o início, publicados.

Palavras-chave: Artigos retratados. Má conduta na pesquisa. Integridade na pesquisa. Comunicação científica.

\section{Introduction}

Since the creation of the first journals, the dissemination of research results and information through scientific articles has become a fundamental activity for scientific advancement, in which incremental or disruptive innovations are developed and reported to the scientific community. Bar-llan and Halevi (2020), for instance, point out that the "standing on the shoulders of giants" aphorism attributed to the physicist Isaac Newton refers to scientific advance supported by previous discoveries.

However, over the years and more recently, in the scenario of the Coronavirus Disease 2019 (COVID-19) pandemic, serial retractions, including cases in reputable journals such as The Lancet and the New England Journal of Medicine, have promoted debates on the issue (Bramstedt, 2020; Freckelton, 2020). Even after retraction and wide media dissemination (Piller, 2021), some articles continue to be cited, generating misinformation, setbacks and, within the scope of issues associated with the ongoing pandemic, public health problems that could impact the entire globe (Péretz et al., 2021; Santos-d'Amorim; Melo; Santos, 2021).

While it is difficult to outline precisely the behaviors driving practices that range from honest mistakes to deliberate misconduct, intentionality is a key element for understanding why an article might be retracted (Fanelli, 2009). The three main reasons are: (i) misconduct; (ii) unintentional errors; and (iii) editorial errors, as categorized by Bar-Ilan and Halevi (2018).

The complexity of the study of retracted articles $^{3}$ in scholarly communication allows a variety of approaches. First, there seems to be a consensus that retractions constitute a device for cleaning up the literature and correcting the scientific record (Allison et al., 2016; Fanelli, 2013; Goodstein, 2010; Ribeiro; Vasconcelos, 2018). Second, the literature raises questions about integrity and misconduct in research (Campos-Varela; Ruano-Raviña, 2019; Stewart; Feder, 1987; van Noorden, 2011), with the prevalence of misconduct being frequently reported over the years (Almeida et al., 2016; Steen, 2011; Fang; Steen; Casadevall, 2012; Hesselmann et al., 2017 Stavale et al., 2019). In this sense, Vasconcelos (2012) points out that scientific integrity should be addressed as a grand challenge in contemporary science. Third, there are discussions about productivism and its "publish or perish" premise, which generate intense competition among scientists (Feenstra et al., 2021; Garfield, 1987; Jawaid, 2016; Lei; Zhang, 2018; Oliveira, 2015; Oransky, 2015), despite some dissent on this theme (Fanelli; Costas; Larivière, 2015). And fourth, one encounters discussions associated with the post-retraction-citations problem, when retracted research is used to support and validate subsequent research (Santos-d'Amorim; Melo; Santos, 2021). Thus, the phenomenon of misinformation is also present in science, as reminded by Bar-llan and Halevi's (2020) allusion to retracted articles as the scientific version of fake news.

Discussions about the impact of retracted literature have been an object of concern from the 1990s (Garfield; Welljams-Dorof, 1990; Pfeifer; Snodgrass, 1990) to the present day (Bar-llan; Halevi, 2017; Bolboacă et al., 2019; Schneider et al., 2020; Teixeira da Silva; Bornemann-Cimenti, 2017). Many studies have investigated retracted publications with a focus on different knowledge areas (Al-Ghareeb et al., 2018; Bauchner et al., 2018; Chauvin et al., 2019; Drimer-Batca; laccarino; Fine, 2019; Feenstra et al., 2021). In Brazil, Stavale et al. (2019) analyzed the

\footnotetext{
${ }^{3}$ The terminology used here for the terms "retracted articles" and "retractions" is interchangeable.
} 
articles retracted on the areas of Health and Life Sciences. However, to the extent of our awareness, the study of the retracted literature without distinction of knowledge areas in Brazil is still insufficiently explored or absent.

Given these inferences, this research's main aim is to characterize the retractions in Brazilian science from 2002 to 2019, relating them to their consequences and impacts on science and scientific activity. As results, we characterize the quantitative aspects of retractions of scientific articles referring to (a) the reasons for retractions; (b) their stratification by knowledge areas; (c) the time between the publication and its retraction; (d) the association between the journals and their impact factors; (e) the distribution of retractions by the number of authors of the articles; ( $f$ ) author recidivism; (g) institutional collaboration between Brazilian institutions and other countries; (h) funding sources. We also identify the consequences and impacts of this phenomenon in the Brazilian context.

In the light of these considerations, the research problem is guided by the following questions: RQ1: How are the retracted articles in the Brazilian scientific production characterized? RQ2: What are the potential impacts and consequences of the retracted articles on scientific communication and the individual's professional activity as a researcher? We assume for that investigation that retractions correct the scientific record by alerting the scientific community and the society that the research contains some problem through retraction notices.

\section{Data and Methods}

The data for this paper were recovered from the Retraction Watch (RW) database, accessed in January 2020. We collected retractions between 2002 and 2019 using the following search strategy: we typed "BRAZIL" in the "Country" field, to delimit the Brazilian scientific production; and selected "RETRACTION" in the "Nature of Notice" drop-down menu, in order to return already retracted papers, excluding those still under investigation. Thereafter, the reasons for retraction were analyzed through the captions available in RW, and these were confirmed by reading the retraction notices accessed by the Digital Object Identifier (DOI) of each paper. Without the demarcation of a particular time frame, this search strategy recovered all the Brazilian retractions whose researchers were affiliated to Brazilian institutions; at the moment that this research was conducted, a total of 165 articles had been retracted.

Duplicate results $(n=2)$ and the ones without any clear information $(n=1)$ were excluded from the analysis subset. Finally, 162 papers composed the investigated sample. The following information was extracted and organized for analysis: (1) date of the original publication; (2) date of retraction; (3) reasons for retraction; (4) time until the retraction; (5) scientific field and subfield; (6) name of the journal and its Impact Factor, as in Clarivate Analytics' Journal Citation Reports (JCR) for 2019; (7) funding sources; (8) author's affiliation, and (9) international collaboration.

To correlate the published papers versus the retracted ones, the scientific production was stratified by each institution involved and by their geographical distribution in each state of the country. The strategy for computing the publications by institution is given by the sum of all papers (paper, review, and letter) indexed in the Web of Science database between 2002 and 2019, with the search strategy delimited to the Organization-Enhanced field. An analysis was performed for each institution using the same delimitation. About the classification of the retractions by knowledge area, we used Glänzel and Schubert's (2003) knowledge area classification scheme due to its level of detail.

\section{Results}

Based on the data obtained, 162 articles were retracted in the period between 2002 and 2019. Of these, 97 (59.9\%) were retracted due to some form of misconduct, 31 (19.1\%) for unintentional errors, and 24 (14.8\%) for mistakes of the journal/editor. It was not possible to identify any information regarding 10 articles (6.1\%). 
Table 1 classifies these retractions according to the following criteria: a typology of the documents, the publication language, authorship, collaboration with other countries, the journal's Impact Factor, institutional affiliation, and funding sources.

\section{Journals, Impact Factor, and recidivism}

Figure 1 (a) systematizes the behavior of the retracted articles. The data analyzed show that most retractions occurred within the first year of publication, with an average time of 2.7 years before the retraction. The dotted lines show exponential decays fitted to the number of retracted papers as a function of year of retraction. For this analysis, we applied an interpretive scale in years; therefore, articles published and retracted in the same year have a retraction time equal to zero on this scale. The average retraction time was calculated by the weighted average, considering the number of retracted papers as the weights.

Table 1 - Characteristics of retractions.

\begin{tabular}{|c|c|c|}
\hline Characteristic & Retractions & $\%$ \\
\hline \multicolumn{3}{|l|}{ Document typology } \\
\hline Article & 160 & 98.7 \\
\hline Conference paper & 1 & 0.6 \\
\hline Preprint & 1 & 0.6 \\
\hline \multicolumn{3}{|l|}{ Language of publication ${ }^{\mathbf{a}}$} \\
\hline Portuguese & 15 & 10.9 \\
\hline English & 116 & 84.0 \\
\hline Portuguese and English & 4 & 2.9 \\
\hline Spanish & 2 & 1.5 \\
\hline $\mathrm{N} / \mathrm{A}$ & 1 & 0.7 \\
\hline \multicolumn{3}{|l|}{ Authorship } \\
\hline Single-authored & 4 & 2.5 \\
\hline Co-authored & 23 & 14.2 \\
\hline Multi-authored & 135 & 83.3 \\
\hline \multicolumn{3}{|l|}{ Nationality } \\
\hline Single country publications (only Brazilian authors) & 141 & 87.0 \\
\hline International collaboration & 21 & 13.0 \\
\hline \multicolumn{3}{|l|}{ Impact Factor ${ }^{\mathbf{a}, \mathbf{b}}$} \\
\hline$>5$ & 24 & 17.6 \\
\hline $2-5$ & 52 & 38.0 \\
\hline$<2$ & 25 & 18.0 \\
\hline Without FI & 36 & 26.4 \\
\hline \multicolumn{3}{|l|}{ Institutional affiliations ${ }^{\mathbf{a}}$} \\
\hline Authors from the same institution & 42 & 30.4 \\
\hline Authors from more than one institution & 90 & 65.2 \\
\hline N/A & 6 & 4.3 \\
\hline \multicolumn{3}{|l|}{ Funding sources ${ }^{\mathbf{a}}$} \\
\hline Funded & 71 & 51.4 \\
\hline Non-funded & 46 & 33.3 \\
\hline $\mathrm{N} / \mathrm{A}$ & 21 & 15.2 \\
\hline
\end{tabular}

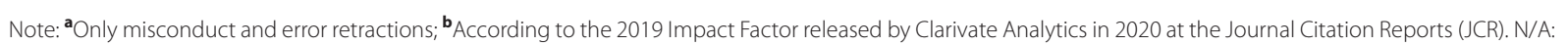
Not Available.

Source: Elaborated by the authors (2020). 
(a)

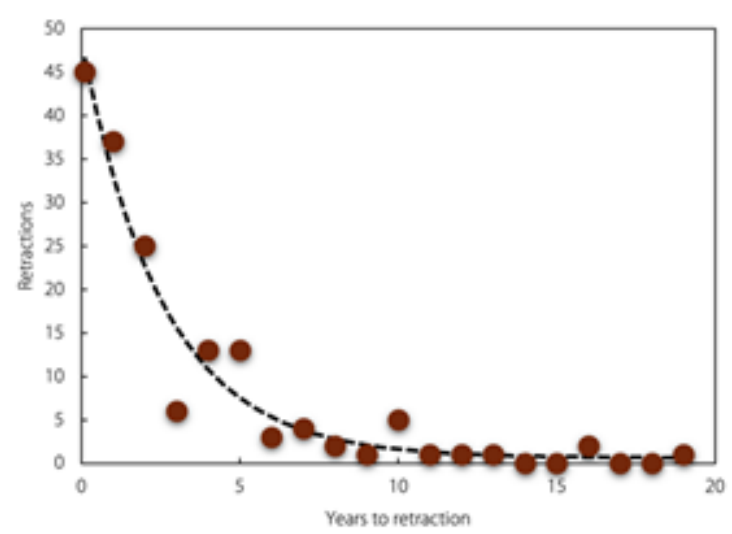

(b)

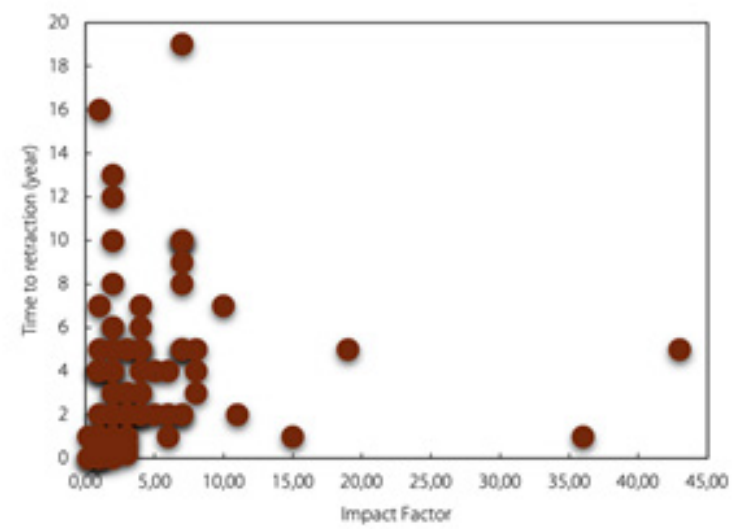

Figure 1 - Number of papers retracted as a function of (a) retraction time; and (b) as a function of the journals' Impact Factor. Source: Elaborated by the authors (2020).

Regarding the journals' Impact Factor (JIF), considering the cases of misconduct and errors, 137 retracted articles had been published by 114 journals. Thirty six of them are not indexed in the 2019 Journal Citation Reports (JCR). Of the 114 journals, 36 are edited in Brazil and issued 37 retractions. Out of those 36, only seven had Journal Impact Factors, which were on a scale ranging from 0.236 to 1.689 . The journals with the highest JIF were Nature (JIF 43.070) and Cell (JIF 36.216).

Regarding the correlation between the time until the retraction as a function of the Impact Factor, there are different variations for articles published in journals with Impact Factors below five. Figure $1(b)$ describes this behavior. For this analysis, we also considered articles published and retracted in the same year as having a retraction time of zero on the applied time scale (annual).

In brief, we found 24 retractions (17.6\%) in journals with impact factors higher than five; 52 retractions (38.0\%) in journals with JIF between 2 and 5; 25 retractions (18.0\%) in journals with impact factors under 2, and 36 retractions (26.4\%) in journals without JIF. The journals with the highest number of retractions are Diabetes $(n=7 / \mathrm{JIF}=7.199)$, Plos One $(n=3 / \mathrm{JIF}=2.776)$, FEBS Letters $(n=3 / \mathrm{JIF}=2.675)$ and Inorganic Chemistry Communications $(n=3 / \mathrm{JIF}=1.795)$.

By analyzing the authors' recidivism in these articles, we found the recidivism of at least one author in seven retracted articles, one author in six retracted articles, and one author in five retracted articles, all of these in the journal Diabetes. We found repeated cases in the journals FEBS Letters and Plos One - the same authors responsible for retractions in the journal Diabetes were also authors in all three retractions in the journal FEBS Letters and two retractions in the journal Plos One, concluding that two authors are responsible for 12 and 11 retractions, respectively. According to Steen's theory (2011), they are considered "repeat offenders" with similar or identical reasons for retraction. We also found the recurrence of other authors in three retractions in the journal Inorganic Chemistry Communications. In all cases of recidivism, all retractions were due to some form of misconduct.

\section{Reasons for retraction}

Overall, the most relevant causes for retraction are misconduct, unintentional erros, and editorial errors. With a manual analysis of the articles, we identified 22 reasons for retractions. As some of the retractions had multiple reasons, we identified 204 incidences in 152 retractions. In 10 articles, it was not possible to identify the reasons for retraction, as the notices did not follow the guidelines of research integrity offices such as COPE (Wager et al., 2009), not providing clear information about the reasons for retraction. 
With regard to articles retracted due to misconduct, we identified cases of: plagiarism, self-plagiarism, and euphemisms for plagiarism ( $n=25 / 12.2 \%)$; duplicate publication ( $n=19 / 9.3 \%)$; image duplication ( $n=18 / 8.8 \%)$; authorship concerns/issues ( $n=16 / 7.8 \%$ ); image manipulation/fabrication ( $n=11 / 5.4 \%)$; falsification/manipulation of results $(n=11 / 5.4 \%)$; data duplication ( $n=6 / 2.9 \%)$; submission without the approval of the coauthors $(n=5 / 2.4 \%)$; submission of the same article to two or more journals ( $n=1 / 0.5 \%)$; and forged authorship $(n=1 / 0.5 \%)$.

Retractions justified by errors include: Journal/Publisher/editorial errors ( $n=24 / 11.8 \%$ ); errors in methods ( $n=12 / 5.9 \%)$; errors in analyses ( $n=9 / 4.4 \%)$; errors in data ( $n=8 / 3.9 \%)$; errors in the results/conclusions $(n=6 / 2.9 \%)$; errors in images ( $n=3 / 1.5 \%)$; irregular formatting of citations ( $n=2 / 1.0 \%)$; and errors in materials $(n=1 / 0.5 \%)$. We also found cases which, depending on the authors' intentionality, can be classified either as misconduct or as errors, such as: non-reproducible results ( $n=13 / 6.4 \%)$; unreliable data ( $n=10 / 4.9 \%)$; and copyright claims $(n=3 / 1.5 \%)$.

\section{Retractions by science fields}

For this stratification, we considered the articles retracted due to misconduct ( $n=99)$ and errors $(n=29)$. Articles retracted for editorial errors ( $n=24)$, in addition to 10 articles that had been withdrawn were excluded from the analysis. The retractions were identified in the fields of:

a)Biosciences ( $n=36 / 28.1 \%$ ), of which 27 articles had been retracted due to misconduct and nine due to errors.

b) Clinical and Experimental Medicine II ( $n=23 / 18.0 \%)$, of which 15 articles had been retracted for misconduct and eight for errors.

c) Chemistry ( $n=22 / 17.2 \%)$, of which 21 articles had been retracted for misconduct and one for errors.

d) Clinical and Experimental Medicine I $(n=11 / 8.6 \%)$, of which seven articles had been retracted for misconduct and four for errors.

e)Biomedical research ( $n=8 / 6.2 \%)$, of which seven articles had been retracted due to misconduct and one due to errors.

f) Biology ( $n=7 / 5.5 \%)$, of which five articles had been retracted due to misconduct and two due to errors.

g) Agriculture and Environment ( $n=5 / 3.9 \%)$, of which three articles had been retracted due to misconduct and two due to errors.

h) Social sciences I ( $n=4 / 3.1 \%)$, with four articles retracted for misconduct.

i) Social sciences II ( $n=4 / 3.1 \%)$, with four articles retracted for misconduct.

j) Engineering $(n=3 / 2.3 \%)$, with two articles retracted for misconduct and one due to errors.

k) Neuroscience and Behavior ( $n=3 / 2.3 \%$ ), with two articles retracted due to misconduct and one due to errors.

I) Arts and Humanities ( $n=1 / 0.8 \%)$, with one article retracted due to misconduct; and

m) Mathematics ( $n=1 / 0.8 \%$, with one article retracted due to misconduct.

In short, the results show that the areas of Biosciences, Clinical and Experimental Medicine II, and Chemistry combined concentrate $63.3 \%$ of the retractions in the investigated corpus.

\section{Number of authors and their distribution in the retracted articles}

Regarding authorship, the results of the survey show that articles with a number of authors/co-authors between two and four accounted for 63 of the retracted articles (38.8\%), followed by collaborative works with five to seven authors ( $n=49 / 30.2 \%)$, eight or more authors $(n=46 / 28.4 \%)$, and articles with only one author $(n=4 / 2.5 \%)$. 
We only considered articles retracted due to misconduct and errors for this analysis, excluding the editorial errors ( $n=24)$. Hence, there was a prevalence of collaborative articles with authors from more than one institution ( $n=90 / 65.2 \%)$, followed by authors from the same institution ( $n=42 / 30.4 \%)$. Six of these articles (4.3\%) were not available for consultation.

\section{Institutional collaboration: articles retracted by Brazilian institutions}

Our study adopted the ethical dimension of scientific research (Bufrem, 2013), guaranteeing the anonymity of the subjects observed through the authorship of the analyzed retracted articles. Hence, the institutions to which the researchers were affiliated and that had at least two retracted papers are listed in Table 2. The incidence of retractions was also correlated with the scientific production indexed in the Web of Science (WoS) database. This incidence was normalized to represent the number of retractions for every 10,000 articles published.

The University of Campinas (Unicamp) ( $n=35)$ and the University of São Paulo (USP) ( $n=19)$ were the institutions with the highest number of retracted articles. Briefly, observing the data in Table 2, misconduct is prevalent ( $n=90 / 65.7 \%$ ) among these cases, while $26.3 \%$ of the articles had been retracted due to some kind of error ( $n=36)$ type. Of these, $8.0 \%(n=11)$ had been withdrawn.

Other institutions were excluded from Table 2 for having only one retraction (misconduct or error). These are illustrated in Figure 2, in absolute numbers and in association with the institutions already presented above.

Table 2. Papers retractions by institution*.

\begin{tabular}{|c|c|c|c|c|c|c|}
\hline \multirow{2}{*}{ Institution } & \multicolumn{4}{|c|}{ Retractions } & \multirow{2}{*}{ Documents indexed at WoS } & \multirow{2}{*}{ Retractions per 10.000 papers } \\
\hline & E & M & N/A & Total & & \\
\hline Universidade Estadual de Campinas & 3 & 32 & - & 35 & 48,316 & 7.2 \\
\hline Universidade de São Paulo & 9 & 8 & 2 & 19 & 144,911 & 1.3 \\
\hline Universidade Federal do Rio Grande do Sul & - & 6 & - & 6 & 37,423 & 1.6 \\
\hline Universidade Estadual Paulista & - & 6 & - & 6 & 52,447 & 1.0 \\
\hline Centro Brasileiro de Pesquisas Físicas & 1 & 3 & - & 4 & 5,419 & 7.3 \\
\hline Universidade Federal de Minas Gerais & 2 & - & 1 & 3 & 34,749 & 0.8 \\
\hline Universidade Estadual de Maringá & - & 3 & - & 3 & 10,418 & 2.8 \\
\hline Universidade Federal de Viçosa & 2 & 1 & - & 3 & 15,486 & 1.9 \\
\hline Universidade Federal do Espírito Santo & 2 & 1 & - & 3 & 7,600 & 3.9 \\
\hline Universidade Federal de Mato Grosso & - & 3 & - & 3 & 12,219 & 2.5 \\
\hline Fundação Oswaldo Cruz & - & 1 & 1 & 2 & 20,641 & 1.0 \\
\hline Pontifícia Universidade Católica de São Paulo & - & 2 & - & 2 & 1,472 & 13.5 \\
\hline Universidade Estadual de Londrina & 1 & - & 1 & 2 & 8,470 & 2.4 \\
\hline Instituto Adolfo Lutz & 1 & - & 1 & 2 & 1,642 & 12.0 \\
\hline Universidade Federal de Campina Grande & - & 2 & - & 2 & 4,197 & 4.8 \\
\hline Universidade Federal da Bahia & 1 & 1 & - & 2 & 11,216 & 1.8 \\
\hline The other public institutions & 8 & 11 & 5 & 24 & - & - \\
\hline The other private institutions & 6 & 10 & - & 16 & - & - \\
\hline Total & 36 & 90 & 11 & 137 & - & - \\
\hline
\end{tabular}

Note: ${ }^{*}$ In absolute numbers (second column), in relation to the scientific production indexed at WoS (third column) and normalized (fourth column) per 10,000 papers published by institution. Retracted articles due editorial errors $(n=24)$ and one conference paper were not considered for analysis. E: retractions due to error; M: retractions due to misconduct; N/A: Not Available; WoS: Web of Science.

Source: Elaborated by the authors (2020). 


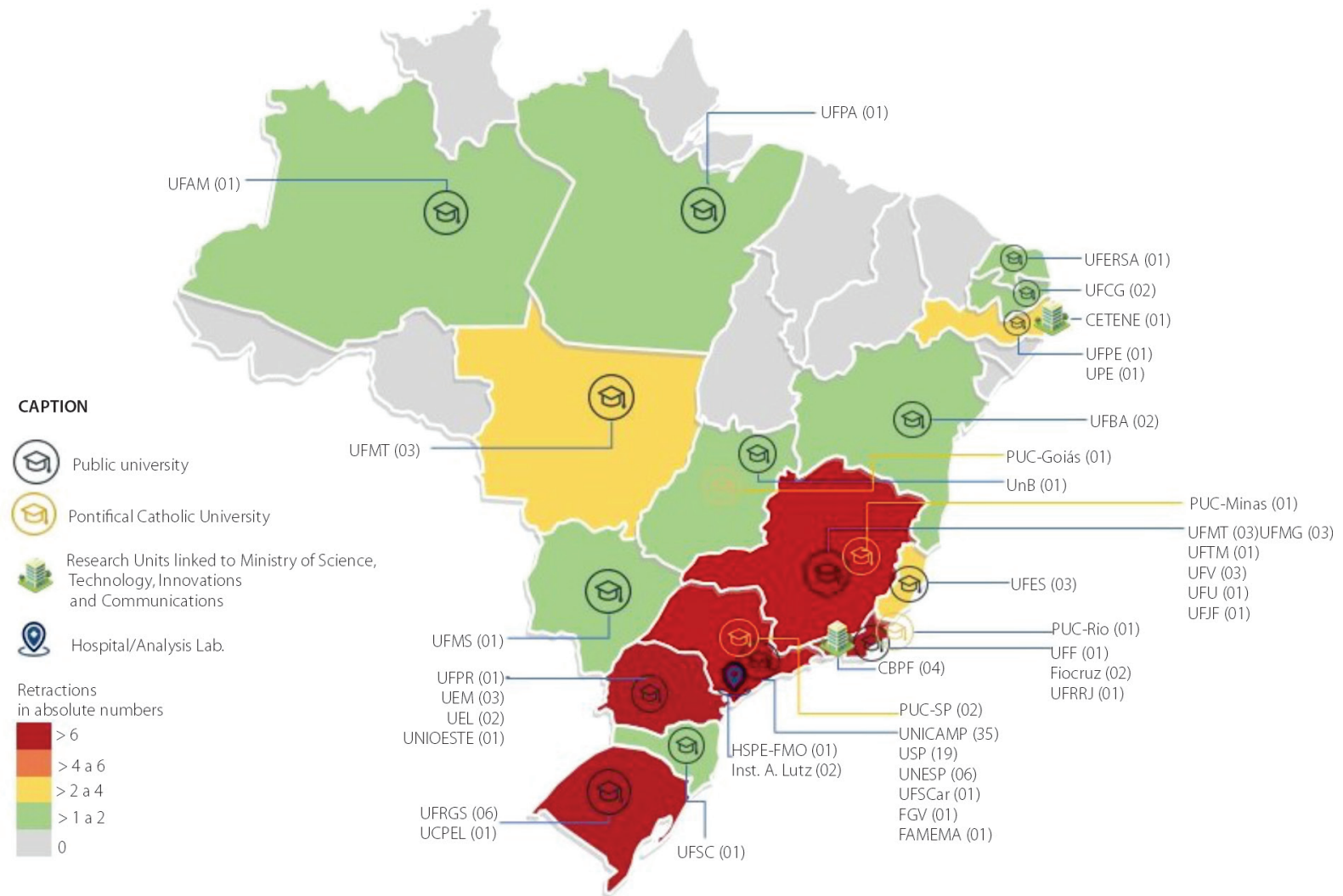

Figure 2 - Retractions by institution.

Universidade Federal do Amazonas (UFAM), Universidade Federal do Pará (UFPA), Universidade Federal Rural do Semiárido (UFERSA), Universidade Federal de Campina Grande (UFCG), Centro de Tecnologias Estratégicas do Nordeste (CETENE), Universidade Federal de Pernambuco (UFPE), Universidade de Pernambuco (UPE), Universidade da Bahia (UFBA), Pontifícia Universidade Católica de Goiás (PUC-Goiás), Universidade de Brasília (UnB), Pontifícia Universidade Católica de Minas Gerais (PUC-Minas), Universidade Federal de Minas Gerais (UFMG), Universidade Federal do Triângulo Mineiro (UFTM), Universidade Federal de Viçosa (UFV), Universidade Federal de Uberlândia (UFU), Universidade Federal de Juiz de Fora (UFJF), Universidade Federal do Espírito Santo (UFES), Pontifícia Universidade Católica do Rio de Janeiro (PUC-Rio), Universidade Federal Fluminense (UFF), Fundação Oswaldo Cruz (Fiocruz), Universidade Federal Rural do Rio de Janeiro (UFRRJ), Centro Brasileiro de Pesquisas Físicas (CBPF), Pontifícia Universidade Católica de São Paulo (PUC-SP), Universidade Estadual de Campinas (Unicamp), Universidade de São Paulo (USP), Universidade Estadual Paulista "Júlio de Mesquita Filho"(UNESP), Universidade Federal de São Carlos (UFSCar), Fundação Getúlio Vargas (FGV), Faculdade de Medicina de Marília (FAMEMA), Hospital do Servidor Público Estadual Francisco Morato de Oliveira (HSPE-FMO), Instituto Adolfo Lutz, Universidade Federal de Santa Catarina (UFSC), Universidade Federal do Rio Grande do Sul (UFRGS), Universidade Católica de Pelotas (UCPEL), Universidade Estadual do Oeste do Paraná (Unioeste), Universidade Estadual de Londrina (UEL), Universidade Estadual de Maringá (UEM), Universidade Federal do Paraná (UFPR), Universidade Federal do Mato Grosso do Sul (UFMS) e Universidade Federal do Mato Grosso (UFMT).

Source: Elaborated by the authors (2020).

Except for the Pontifical Catholic Universities (PUC, Pontifícia Universidade Católica), the following institutions and their respective retractions were not included in Figure 2, despite being part of our corpus, as they are private institutions: Escola Bahiana de Medicina e Saúde Pública $(n=1)$, Universidade La Salle $(n=1)$, Centro de Pesquisa Biotecnos $(n=2)$, Universidade Cruzeiro do Sul ( $n=1)$, Universidade do Extremo Sul Catarinense ( $n=1)$, Instituto do Cérebro do Hospital Israelita Albert Einstein ( $n=1)$, Associação dos Diabéticos de Bauru $(n=2)$, Centro Universitário de Belo Horizonte $(n=1)$, Universidade São Francisco $(n=1)$, Universidade do Vale do Itajaí $(n=1)$, Universidade Paulista $(n=1)$, Universidade Luterana do Brasil (n=1), Faculdade de Ciências Médicas da Santa Casa de São Paulo (n=1), and Seção de Pós-Graduação da Escola de Aperfeiçoamento de Oficiais do Exército $(n=1)$.

\section{International Collaboration}

Employing the association strength analysis method (van Eck; Waltman, 2009), the map in Figure 3 illustrates Brazil's international collaboration with 17 countries. With an analysis of authorship and co-authorship, we found 28 
articles resulting from these collaborations, with the largest number of interactions being with the United States of America ( $n=4)$, India ( $n=4)$, Germany $(n=3)$, followed by Canada ( $n=2)$, the United Kingdom $(n=2)$, and Spain $(n=2)$.

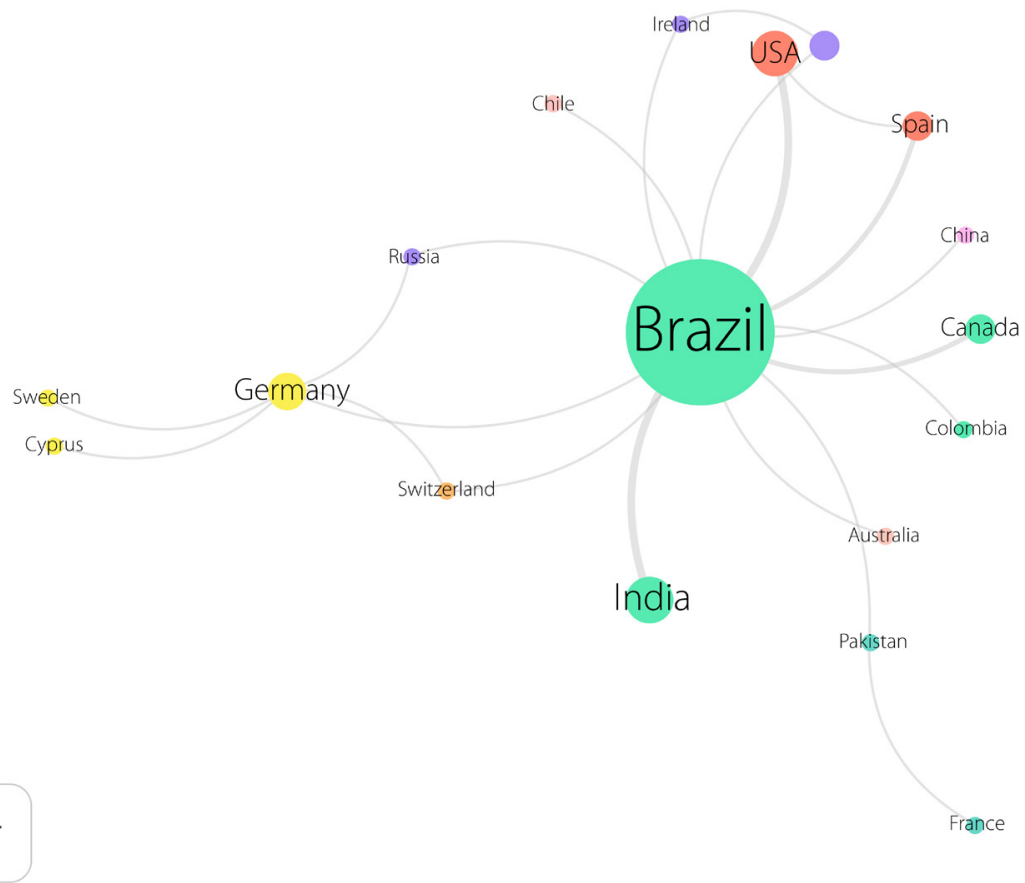

Figure 3 - International collaborative countries (authorship and co-authorship) of Brazilian retractions. Source: Elaborated by the authors (2020).

\section{Funding sources}

Whereas some researches were funded by more than one agency, after manually checking the sources of funding declared in the retractions, we identified that $38.4 \%(n=53)$ were funded by the National Council for Scientific and Technological Development (CNPq, Conselho Nacional de Desenvolvimento Científico e Tecnológico) and 29.7\% ( $n=41)$ were funded or co-funded by the São Paulo Research Foundation (Fapesp, Fundação de Amparo à Pesquisa do Estado de São Paulo). Both are public institutions and the ones that invest the most in research in the country. There was also an incidence of funding from other public institutions: the Coordination for Higher Education Staff Development (Capes, Coordenação de Aperfeiçoamento de Pessoal de Nível Superior) in 17 retracted articles; the Funding Authority for Studies and Projects (Finep, Financiadora de Estudos e Projetos), in four articles; and the Foundation for Research Support of the State of Minas Gerais (FAPEMIG, Fundação de Amparo à Pesquisa do Estado de Minas Gerais), in three articles. Other 19 institutions funded at least one research that resulted in a retracted article. It is also noteworthy that $33.3 \%$ of the retractions were not financed research $(n=46)$, and it was not possible to verify the sources of funding in 21 articles because they were no longer available for consultation in the original.

\section{Discussion}

From the analysis of the data obtained from the 162 articles retracted, authored or co-authored by Brazilian researchers, we identified that $61.1 \%(n=99)$ of these articles had been retracted due to some case of misconduct; 
17.9\% ( $n=29)$ for unintentional errors, and 14.8\% ( $n=24)$ for editorial errors. A percentage of $6.1 \%(n=10)$ had been withdrawn, limiting the analysis of these articles.

The results presented show the prevalence of plagiarism (12.2\%) among the reasons for the retraction of articles published by Brazilian researchers. The result is similar to the one found by Almeida et al. (2016), who analyzed the retractions indexed in the Scientific Electronic Library Online (SciELO) and Latin American and Caribbean System on Health Sciences Information (Lilacs) databases.

Based on data collected from the Retraction Watch, the first retraction notice was published in 2002, reporting errors in the analyses, methods, and research results. Assessing the retractions between 1982 and 2002 in the Medical Literature Analysis and Retrieval System Online (Medline) databases, Nath, Marcus and Druss (2006) highlight the prevalence of retractions for errors (61.8\%), whereas the ones related to misconduct were much more limited (27.1\%). In our study, we found the first report of a misconduct-related retraction in 2004, specifying plagiarism and third-party objections. It is only in 2009 that research misconduct begins to stand out as the main reason for retraction, a result similar to those found in other contexts (Bauchner et al., 2018; Campos-Varela; Ruano-Raviña, 2019; Drimer-Batca; laccarino; Fine, 2019). In a broad perspective, when considering the sum of the reasons for retraction associated with the main causes, misconduct is highlighted by the survey, accounting for $52.9 \%$ of all retractions.

Regarding scientific fields, we identified the prevalence of retracted articles in the areas of: Biosciences (28.1\%), with 27 retractions for misconduct and nine for errors; Clinical and Experimental Medicine II (18.0\%), with 15 articles retracted due to misconduct and eight for errors; and Chemistry (17.2\%), with 21 articles retracted for misconduct and one for errors. The percentages presented are in reference to the total number of articles retracted. Some studies reveal patterns of retraction in these areas. Naturally, areas with more articles published will more likely present a higher number of retracted articles. This factor was not quantified due to the difficulty of access to the number of publications broken down by science fields.

Analyzing the retractions in the field of Medicine using Medline and Retraction Watch databases, Al-Ghareeb et al. (2018) found that misconduct, more precisely, duplicate publications, was the most common reason for retractions in the field. Chauvin et al. (2019) tracked all retractions in Medline, Web of Science, and Cochrane Central Register of Controlled Trials on Emergency Medicine, and similarly found the prevalence of misconduct, among which plagiarism and duplicate publications were most frequently noted in the investigated corpora. Stavale et al. (2019) examined PubMed, Web of Science, Biblioteca Virtual em Saúde (BVS), and Google Scholar, and they also found that the most common reasons for retraction in Health and Life Sciences in Brazil are also related to research misconduct.

In view of the evidence presented, research misconduct (plagiarism, duplicate publication, fabrication of data, falsification of figures, manipulations, and the like) has been a recurring subject in discussions about retractions. In contrast to this trend, Fanelli (2013) argues that there is little evidence of increases in research misconduct. For the author, "[t]he recent rise in retractions, therefore, is most plausibly the effect of growing scientific integrity, rather than growing scientific misconduct" (Fanelli, 2013, p. 4). One explanation is what he called a "stronger system", which includes the creation of legal guidelines for combating misconduct, the skills that publishers and authors acquired in detecting plagiarism from online tools, as well as the fact that researchers have become more aware of these issues.

Concerning the low rate of retractions in the Social Sciences (I and II) and in the Arts and Humanities, one hypothesis highlights the subjective nature of the cited sciences. In general, the Exact, Health, and Biological Sciences lean towards being "self-correcting" since a work that cannot be replicated or reproduced - be it due to misconduct or errors in methods, including honest mistakes - can be identified from the very attempt of reproducibility of the study (Budd; Sievert; Schultz, 1998), whereas the Applied Social Sciences or the Humanities may have a subjective 
character. Another hypothesis for the low rate of retractions in the Social Sciences (I and II) and Arts and Humanities is that these sciences are still in the early stages of establishing and developing retraction protocols and procedures in their journals. In the health sciences, the International Committee of Medical Journal Editors (ICMJE) was created in 1978 to guide and conduct ethical guidelines in biomedical research (van der Weyden, 2007), which remains active until today. Thus, retraction protocols and procedures were developed initially in the health sciences, corroborating this area's the higher efficiency in detecting problems, with these procedures migrating only later to other areas.

Regarding the journals' Impact Factor, we observed the prevalence of retractions in journals between 2 and 5 JIF (n=52/38.0\%). Concerning this, Nath, Marcus and Druss (2006, p. 153) point out that "the large volume of articles published in these journals may naturally increase the rate of error among them". The average time for retraction in the research corpus was 2.7 years, and articles published in journals with a JIF higher than five seem to take less time to retract. One should also consider that well-established journals have clear policies for retraction (Resnik; Wager; Kissling, 2015). Despite the information presented, data that can serve to characterize a pattern is still limited.

Regarding institutions, we found that the Unicamp, followed by the USP, lead the ranking of universities with more articles retracted, with 35 and 19 retractions, respectively. On the other hand, a correlation made based on the documents (paper, review, and letter) indexed in WoS, shows that these two institutions lead the ranking of publications. Consequently, institutions that publish the most may naturally be more likely to have articles retracted. Table 2 presents these results in terms of the percentage of retracted articles in relation to the total number of articles published in the institution, thus correcting possible distortions. In percentage terms, Unicamp ranks among the institutions with the highest retraction rate, along with CBPF, PUC-SP, and the Adolfo Lutz Institute, while USP has the lowest retraction rate when corrected by the total number of published articles.

We also noted the prevalence of retractions among articles whose authorship counted between 2 and 4 authors (38.8\%). Inversely, articles with only one author showed the lowest percentage (2.5\%) of retraction. The prevalence of retractions in multi-author articles is due to the very frequency of research developed in collaboration, characterized by involving multicenter and multidisciplinary teams, especially in the health, biomedical, and exact sciences and nature in general, as highlighted by An et al. (2020).

The authorship and co-authorship analysis identified Brazil's international collaboration with 17 countries. We highlight the cooperation with countries that already have consolidated research integrity policies, such as the United States and Germany (Tavare, 2011), both with four retractions. With regard to funding sources, as almost all scientific research in the country is conducted with public resources, it was found that $51.4 \%(n=71)$ of the research in the retracted articles was funded by agencies of this nature.

We observed that the agencies that finance most research in the country, CNPq, and Fapesp, are unsurprisingly the ones that figure more often among the institutions with financed articles later retracted, appearing as funders in 53 and 41 publications, respectively. It should also be taken into consideration that the same research can have multiple funders. Stern et al. (2014) report some findings on the topic in the U.S. scenario, highlighting articles retracted for misconduct which counted on funding from the National Institutes of Health (NIH), the main agency to fund biomedical research in the United States. Although representing not very significant numbers proportionally, Vasconcelos (2012) reports that based on concerns about the waste of public resources on these researches, important policies of integrity in research have been developed. The United States, Germany, and Scandinavian countries, for example, already have well-defined policies to address the issue (Tavare, 2011).

In Brazil, in 2011, when retractions of articles published by Brazilian researchers increased, CNPq established the Commission for Integrity in Scientific Activities (CIAC, Comissão de Integridade na Atividade Científica), which instituted 21 basic guidelines concerning scientific integrity in that same year, thus guaranteeing more security to the quality of research in the country. In the same sense and also in 2011, Fapesp published the first version of its 
Code of Good Scientific Practices. Updated in 2014, the Code has measures ranging from the obligation to correct the scientific record to the cancellation of grants or scholarships awarded to the responsible party, in addition to the return of granted resources and the avoidance of applying for new grants (Fapesp, 2014).

In addition to the quantitative indicators presented, the possible impacts and consequences resulting from retractions are cited as follows. They refer mainly, but not exclusively, to cases of recidivism of retractions for misconduct in the professional activity of the researcher, as well as in science.

(1) Invalidation of degrees: considering that most graduate programs in Brazil require publications of scientific articles related to the research developed in thesis and dissertations as part of the criteria for obtaining degrees, one of the consequences for research misconduct, evidenced by the retraction of an article, is the invalidation of degrees. Damasio (2017), for example, reports a factual example of title invalidation following a complaint that reported image fraud in a scientific publication.

(2) Copyrights: regarding copyrights associated with plagiarism in the Brazilian legal system, the Copyright Law (9.610/1998) establishes that scientific texts are protected intellectual work, among other protected documents, and provides civil and criminal penalties for violators. Institutionally, the recommendation of Capes is based on guidelines from the Brazilian Bar Association (OAB), in which educational institutions (public and private ones) adopt policies and procedures that aim to curb some practices.

(3) Loss of positions: although there is no specific legislation regarding sanctions for misconduct in research at the national level so far, the suspension, or in more extreme cases, the dismissal of the professor/researcher from their position may be justified after the confirmation or recidivism of misconduct in research. Institutional initiatives such as Fapesp's Code of Good Scientific Practices, already provide some corrective and punitive measures in cases of misconduct. In contrast, Oliveira (2015, p. 892, our translation) ${ }^{4}$ provides a view of what he called the "failure of the moralizing treatment" and proposes "a treatment aimed ideally at suppressing or, more realistically, progressively easing productivist pressures".

(4) Recognition by non-scientific capital: French sociologist Pierre Bourdieu (1930-2002) defines scientific capital as a form of symbolic capital. For Bourdieu, the scientific field is a structure based on the distribution of scientific capital (Bourdieu, 1976). Following this logic, if the researcher becomes known not for his scientific achievements, but for his frauds, this capital takes the opposite direction to that proposed by Bourdieu, which can undermine his career and make possible future achievements more difficult. Azoulay, Bonatti, and Krieger (2017) evaluated that prominent scientists suffer harsher penalties for misconduct, including an average drop by 10\% in citations of their previous works.

(5) Risks to science: although proportionally unrepresentative, the small fraction of problematic retracted articles features prominently on the news, surpassing the frontiers of academia and gaining space in the media, which can contribute to the maintenance of revisionist and denialist movements, as the anti-vaxxers. To this day, movements such as these draw on the case of a 1998 article published in The Lancet, which took 12 years to be retracted. This article attributed a false relationship between the Measles, Mumps, and Rubella (MMR) vaccine and the risk of developing autism, causing a reduction in vaccination rates and a rise in anti-vaxxers movements. Its author was accused of conflicts of interest (Nature Immunology, 2008).

Therefore, we can perceive the need to improve the mechanisms for identifying failures, particularly those involving misconduct, in order to avoid these defective publications.

The efforts to identify flaws in research are not new, but the concerns associated with the reliability of data and the reproducibility of COVID-19 studies have ignited debates on the subject (Bommier; Stœklé; Hervé, 2021;

${ }^{4}$ In the original: "um tratamento visando idealmente suprimir ou, mais realisticamente, amenizar progressivamente as pressões produtivistas" (Oliveira, 2015, p. 892). 
Bramstedt, 2020; Santos-d'Amorim; Melo; Santos, 2021; Vlasschaert; Topf; Hiremath, 2020). Aiming to improve these mechanisms, the editors of The Lancet Group, after the negative repercussions involving a retraction in The Lancet (Mehra; Ruschitzka; Patel, 2020; The Lancet Editors, 2020a), have redefined their peer review process. In a comment on the issue, the editors pointed out ways to reduce the potential risks of misconduct by applying additional peer review requirements to articles originating from large data sets (The Lancet Editors, 2020b). They established that (1) at least one reviewer must know about the dataset details; (2) an additional review will be performed by an expert in data science; (3) a statement that all authors have had full access to the research data set and that more than one author has accessed and verified the data reported in the manuscript is mandatory; (4) and, in the case of articles resulting from academic and commercial partnerships, one of the authors responsible for accessing and verifying the data must be from the academic team (The Lancet Editors, 2020b).

In the context of clinical trials, Ewers, Ioannidis, and Plesnila (2020) point out that open access to the data of patients who participated in these COVID-19-related trials may allow for re-analysis, validation, transparency, and confidence in the results of clinical research, making the reproducibility of these trials reliable. For the authors, the benefits of data openness outweigh the risks, especially in the pandemic of COVID-19. Teixeira da Silva, Bornemann-Cimenti, and Tsigaris (2021) support the idea of peer review process optimization and point out that a rigorous open data policy is needed to minimize the risk of retractions. Aiming to reduce the chances of questionable research publications related to COVID-19, the authors suggest a six-step process: (1) "prescreening [of] a paper by the editor-in-chief with simultaneous advice from an expert editor and a statistician", (2) "independent peer review by at least three experts selected by the journal's editors within three weeks, including full access to raw data"; (3) "an open peer review policy"; (4) "there should be no immediate overnight acceptance [...] authors would have 1-2 weeks to complete minor revisions and 3-4 weeks for major revisions, with another 1-2 weeks for each additional revision [...] reviewers should examine edits within a week and make a decision to reject, accept, or make additional edits"; (5) "the editorial decision should be based on reviewers' recommendations, and acceptance should only be with the unanimous approval of all three reviewers", and (6) "processing a manuscript to publication should take, at most, another 2 weeks, and should include open peer review reports, authors' responses and editorial comments and decisions" (Teixeira da Silva; Bornemann-Cimenti; Tsigaris, 2021, p. 23).

The process proposed by Teixeira da Silva, Bornemann-Cimenti, and Tsigaris (2021) can be generalized to the literature in general, noting mainly the recommendations that address the scope of open access practices, such as making research data available and open peer review, but also recognizing the challenges in applying these measures. Thus, the retractions involving journals with high Impact Factors may serve as an attempt to strengthen policies on the peer-review process.

Despite the limitations inherent to the very delimitation of this study's corpus of analysis, and the fact that the Retraction Watch database indexes information on retractions worldwide without distinguishing between publishers and without covering the totality of the articles retracted, the observations highlighted here aim to contribute to a preliminary local evaluation, not closing the issues associated with the complexity of this research object, but providing subsidies for the integrity of research in the country.

\section{Conclusion}

This exploratory study adds to the literature a discussion on retracted articles in the Brazilian scenario, providing a comprehensive view of the domain. Although retracted articles represent only a small fraction in comparison to the total number of publications as research output in the country, the consequences related to retractions justify discussions on the topic.

Concerning research integrity in Brazil, significant steps have been taken, such as research ethics committees and codes created by institutions and funding agencies in the last decade. We conclude that the majority of the 
retractions in the country in the analyzed period is due to some form of misconduct (61.1\%), whereas $7.9 \%$ is due to some unintentional error type, and $14.8 \%$ to editorial errors. We have also identified $6.1 \%$ withdrawns. Among the misconducts, the results presented show the prevalence of plagiarism (12.2\%) as the main reason those articles were retracted.

In effect, the occurrences that lead to retractions for misconduct and their recidivism have impacts on the professional activity of the researcher, and risks for science.

It is essential to highlight that retractions are an indispensable device for monitoring integrity in the field of scientific research, identifying work involving both research misconduct and unintentional mistakes that may eventually be committed.

In addition to this natural function of retractions, we conclude that they are also significant indicators of the scientific field's behavior, allowing us to evaluate trends proactively, starting before the phenomenon reaches a relevant scale and avoiding possible problems in the broader field of scientific research. In this sense, it is suggested that the number of retracted articles can be used as a trend indicator to warn about the need to improve mechanisms to identify flaws in research, as well as the large-scale application of policies of open access to data and open peer review. In current times, when misinformation is present in all fields, it is suggested that the proportional number of articles that needed to be retracted can be used indirectly to measure risks and factors that contribute to misinformation.

\section{Acknowledgment}

We thank the two anonymous reviewers for their valuable comments on our manuscript.

\section{Contributors}

All authors contributed to the study conception and design. Material preparation, data collection was performed by K. SANTOS-D'AMORIM. Analysis was performed by K. SANTOS-D'AMORIM, M. K. F. O. MIRANDA, A. E. G. C. CORREIA, and P. SANTACRUZ. All authors read and approved the final manuscript.

Allison, D. B. et al. Reproducibility: a tragedy of errors. Nature, v. 530, p. 27-29, 2016. Doi: https://doi.org/10.1038/530027a.

Almeida, R. M. V. R. et al. Plagiarism allegations account for most retractions in major Latin American/Caribbean Databases. Science and Engineering Ethics, v. 22, p. 1447-1456, 2016. Doi: https://doi.org/10.1007/s1 1948-015-9714-5.

Al-Ghareeb, A. Z. et al. Retraction of publications in nursing and midwifery research: a systematic review. International Journal of Nursing Studies, v. 81, p. 8-13, 2018. Doi: https://doi. org/10.1016/j.jinurstu.2018.01.013.

An, J. Y. et al. Authorship growth in contemporary medical literature. Sage Open Medicine, v. 8, p. 1-10, 2020. Doi: https:// doi.org/10.1177/2050312120915399.

Azoulay, P.; Bonatti, A.; Krieger, J. The career effects of scandal: evidence from scientific retractions. Research Policy, v. 46, n. 9, p. 1552-1569, 2017. Doi: https://doi.org/10.1016/j. respol.2017.07.003.
Bar-llan, J.; Halevi, G. Post retraction citations in context: a case study. Scientometrics, v. 113, p. 547-565, 2017. Doi: https://doi. org/10.1007/s11192-017-2242-0.

Bar-Ilan, J.; Halevi, G. Temporal characteristics of retracted articles. Scientometrics, v. 116, p. 1771-1783, 2018. Doi: https:// doi.org/10.1007/s11192-018-2802-y.

Bar-llan, J.; Halevi, G. Retracted articles - the scientific version of fake news. In: Greifeneder, R. et al. (ed.). The Psychology of Fake News: accepting, sharing, and correcting misinformation. Basel: Routledge, 2020. p. 47-70. Doi: https:// doi.org/10.4324/9780429295379.

Bauchner, H. et al. Scientific misconduct and medical journals. Journal of the American Medical Association, v. 320, n. 19, p. 1985-1987, 2018. Doi: https://doi.org/10.1001/jama.2018.14350.

Bramstedt, K. The carnage of substandard research during the COVID-19 pandemic: a call for quality. Journal of Medical 
Ethics, v. 46, p. 803-807, 2020. Doi: https://doi.org/10.1136/ medethics-2020-106494

Bolboacă, S. D. et al. Post retraction citations among manuscripts reporting a radiology-imaging diagnostic method. Plos One, v. 14, n. 6, 2019. Doi: https://doi.org/10.1371/journal.pone.0217918.

Bommier, C.; Stoklé, H.-C.; Hervé, C. COVID-19: the urgent call for academic research in research ethics. Ethics, Medicine and Public Health, v. 18, 2021. Doi: https://doi.org/10.1016/j. jemep.2021.100679.

Bourdieu, P. Le champ scientifique. In: Bourdieu, P. Actes de la recherche en sciences sociales. Paris: Persée, 1976. p. 88-104.

Budd, J. M.; Sievert, M.; Schultz, T. R. Phenomena of retraction: reasons for retraction and citations to the publications. Journal of the American Medical Association, v. 280, n. 3, p. 296-297, 1998. Doi: https://doi.org/10.1001/jama.280.3.296.

Bufrem, L. S. Configurações da pesquisa em ciência da informação. DataGramaZero, v. 14, n. 6, p. 1-13, 2013. Disponível em: https://brapci.inf.br/index.php/article/download/50777. Acesso em: 10 jul. 2020.

Campos-Varela, l.; Ruano-Raviña, A. Misconduct as the main cause for retraction. A descriptive study of retracted publications and their authors. Gaceta Sanitaria, v. 33, n. 4, p. 356-360, 2019. Doi: https://doi.org/10.1016/j.gaceta.2018.01.009.

Chauvin, A. et al. A systematic review of retracted publications in emergency medicine. European Journal of Emergency Medicine, v. 26, n. 1, p. 19-23, 2019. Doi: https://doi.org/10.1097/ MEJ.0000000000000491.

Damasio, E. Práticas de má conduta na comunicação científica e o fluxo editorial: um estudo com editores de revistas científicas SciELO. 2017. Tese (Doutorado em Ciência da Informação) - Universidade Federal do Rio de Janeiro, Rio de Janeiro, 2017.

Drimer-Batca, D.; laccarino, J. M.; Fine, A. Status of retraction notices for biomedical publications associated with research misconduct. Research Ethics, v. 15, n. 2, p. 1-5, 2019. Doi: https://doi.org/10.1177/1747016118820496.

Ewers, M. et al. Access to data from clinical trials in the COVID-19 crisis: open, flexible, and time-sensitive. Journal of Clinical Epidemiology, v. 130, p. 143-146. Doi: https://doi. org/10.1016/j.jclinepi.2020.10.008.

Fanelli, D. Why growing retractions are (mostly) a good sign. Plos Medicine, v. 10, n. 12, 2013. Doi: https://doi.org/10.1371/ journal.pmed.1001563.

Fanelli, D. How many scientists fabricate and falsify research? a systematic review and meta-analysis of survey data. Plos One, v. 4, n. 5, e5738, 2009. Doi: https://doi.org/10.1371/journal. pone.0005738.

Fanelli, D.; Costas, R.; Larivière, V. Misconduct Policies, Academic Culture and Career Stage, not gender or pressures to publish, affect scientific integrity. Plos One, v. 10, n. 6, e0127556, 2015. Doi: https://doi.org/10.1371/journal.pone.0127556.

Fang, F. C.; Steen, R. G.; Casadevall, A. Misconduct accounts for the majority of retracted scientific publications. Proceedings of the National Academy of Sciences of the United States of America, Washington, v. 109, n. 42, p. 17028-17033, 2012.

Feenstra, R. A.; Delgado López-Cózar, E.; Pallarés-Domínguez, D. Research misconduct in the fields of ethics and philosophy: researchers' perceptions in Spain. Science and Engineering Ethics, v. 27, n. 1, p. 1-21, 2021. Doi: https://doi.org/10.1007/ s11948-021-00278-w.

Freckelton I. Perils of precipitate publication: fraudulent and substandard COVID-19 research. Journal of Law and Medicine, v. 27, n. 4, p. 779-789, 2020.

Fundação de Amparo à Pesquisa do Estado de São Paulo. Código de boas práticas científicas. 2014. Disponível em: https://fapesp.br/boaspraticas/FAPESP-Codigo_de_Boas_ Praticas_Cientificas_2014.pdf. Acesso em: 12 mar. 2021

Garfield, E. What do we know about fraud and other forms of intellectual dishonesty in science? Part 2. Why Does Fraud Happen and What Are Its Effects? Current Contents, v. 10, p. 93-100, 1987. Available from: http://garfield.library.upenn. edu/essays/v10p088y1987.pdf. Cited: Jul. 10, 2020.

Garfield, E.; Welljams-Dorof, A. The impact of fraudulent research on the scientific literature: the stephen e. breuning case. Journal of the American Medical Association, v. 263, n. 10, p. 1424-1426, 1990. Doi: https://doi.org/10.1001/ jama.1990.03440100144021.

Glänzel, W.; Schubert, A. A new classification scheme of science fields and subfields designed for scientometric evaluation purposes. Scientometrics, v. 56, p. 357-367, 2003. Doi: https://doi.org/10.1023/A:1022378804087.

Goodstein, D. On fact and fraud. Princeton: Princeton University Press, 2010.

Hesselmann, F. et al. The visibility of scientific misconduct: a review of the literature on retracted journal articles. Current Sociology, v. 65, n. 6, p. 814-845, 2017. Doi: https://doi. org/10.1177/0011392116663807.

Jawaid, S. A. Publish or perish: need to have another look? Pakistan Journal of Medical Sciences, v. 32, n. 2, p. 267-269, 2016. Doi: https://doi.org/10.12669/pjms.322.10326.

Lei, L.; Zhang, Y. Lack of Improvement in scientific integrity: an analysis of WoS retractions by chinese researchers (1997-2016). Science and Engineering Ethics, v. 24, p. 1409-1420, 2018. Doi: https://doi.org/10.1007/s11948-017-9962-7.

Mehra M. R.; Ruschitzka F.; Patel A. N. Retraction hydroxychloroquine or chloroquine with or without a macrolide for treatment of COVID-19: a multinational registry analysis. Lancet, v. 395, p. 1820, 2020. Doi: https://doi. org/10.1016/S0140-6736(20)31324-6.

Nath, S. B.; Marcus, S. C; Druss, B. G. Retractions in the research literature: misconduct or mistakes? Medical Journal of Australia, v. 185, n. 3, p. 152-154, 2006. Doi: https://doi. org/10.5694/j.1326-5377.2006.tb00504.x.

Nature Immunology. A case of junk science, conflict and hype. Nature Immunology, v. 9, n. 2, 2008. Doi: https://doi. org/10.1038/ni1208-1317.

Oliveira, M. B. A epidemia de más condutas na ciência: o fracasso do tratamento moralizador. Scientiae Studia, v. 13, n. 4, p. 867-897, 2015. Doi: https://doi.org/10.1590/S167831662015000400007.

Oransky, I. How publish or perish promotes inaccuracy in science - and journalism. American Medical Association Journal of Ethics, v. 17, n. 12, p. 1172-1175, 2015. Doi: https:// doi.org/10.1001/journalofethics.2015.17.12.sect1-1512. 
Péretz, F. et al. Littérature médicale et COVID-19: comment trois articles ont influencé les médias et la décision publique en France. La Revue de Médecine Interne, 2021. Doi: https://doi. org/10.1016/j.revmed.2021.03.010.

Pfeifer, M. P.; Snodgrass, G. L. The continued use of retracted, invalid scientific literature. Journal of the American Medical Association, v. 263, n. 10, p. 1420-1423, 1990. Doi: https://doi. org/10.1001/jama.1990.03440100140020.

Piller, C. Many scientists citing two scandalous COVID-19 papers ignore their retractions. Science, Washington, Jan. 15, 2021. Scientific Community. Available from: https://www. science.org/news/2021/01/many-scientists-citing-twoscandalous-covid-19-papers-ignore-their-retractions. Cited: Jan. 16, 2021.

Resnik, D. B.; Wager, E.; Kissling, G. E. Retraction policies of top scientific journals ranked by impact factor. Journal of the Medical Library Association, v. 103, n. 3, p. 136-139, 2015. Doi: https://doi.org/10.3163/1536-5050.103.3.006.

Ribeiro, M. D.; Vasconcelos, S. M. R. Retractions covered by retraction watch in the 2013-2015 period: prevalence for the most productive countries. Scientometrics, v. 114, p. 719-734, 2018. Doi: https://doi.org/10.1007/s11192-017-2621-6.

Santos-d'Amorim, K.; Melo, R. R.; Santos, R. N. M. Retractions and post-retraction citations in the COVID-19 infodemic: is Academia spreading misinformation? Liinc em Revista, v. 17, n. 1, p. 1-19, 2021. Doi: https://doi.org/10.18617/liinc.v17i1.5593.

Schneider, J. et al. Continued post-retraction citation of a fraudulent clinical trial report, 11 years after it was retracted for falsifying data. Scientometrics, v. 125, p. 2877-2913, 2020. Doi: https://doi.org/10.1007/s11192-020-03631-1.

Stavale, R. et al. Research misconduct in health and life sciences research: A systematic review of retracted literature from Brazilian institutions. Plos One, v. 14, n. 4, 2019. Doi: https://doi.org/10.1371/journal.pone.0214272.

Steen, R. G. Retractions in the scientific literature: do authors deliberately commit research fraud? Journal of Medical Ethics, v. 37, n. 2, p. 113-117, 2011. Doi: http://dx.doi.org/10.1136/ jme.2010.038125.

Stern, A. M. et al. Financial costs and personal consequences of research misconduct resulting in retracted publications. eLife, v. 3, n. e02956, 2014. Doi: https://doi.org/10.7554/eLife.02956.

Stewart, W. W.; Feder, N. The integrity of the scientific literature. Nature, v. 325, 1987.
Tavare, A. Managing research misconduct: is anyone getting it right? BMJ, v. 343, p. 1-3, 2011. Doi: https://doi.org/10.1136/ bmj.d8212.

Teixeira da Silva, J. A.; Bornemann-Cimenti. H. Why do some retracted papers continue to be cited? Scientometrics, v. 110, 365-370, 2017. Doi: https://doi.org/10.1007/s11192-0162178-9.

Teixeira da Silva, J. A.; Bornemann Cimenti, H.; Tsigaris, P. Optimizing peer review to minimize the risk of retracting COVID 19 related literature. Medicine, Health Care and Philosophy, v. 24, n. 1, p. 21-26, 2021. Doi: https://doi. org/10.1007/s11019-020-09990-z.

The Lancet Editors. Expression of concern: hydroxychloroquine or chloroquine with or without a macrolide for treatment of COVID-19: a multinational registry analysis. Lancet, v. 395, 2020a. Doi: https://doi.org/10.1016/S0140-6736(20)31290-3.

The Lancet Editors. Learning from a retraction. Lancet, v. 396, p. 1056, 2020b. Doi: https://doi.org/10.1016/S01406736(20)31958-9

van der Weyden, Martin B. The ICMJE and URM: providing independent advice for the conduct of biomedical research and publication. Mens Sana Monographs, v. 5, n. 1, p. 15-25, 2007. Doi: https://doi.org/10.4103/0973-1229.32145.

van Eck, N. J.; Waltman, L. How to normalize cooccurrence data? An analysis of some well-known similarity measures. Journal of the American Society for Information Science and Technology, v. 60, n. 8, p. 1635-1651, 2009. Doi: https://doi. org/10.1002/asi.21075.

vanNoorden, R.Sciencepublishing:thetroublewith retractions. Nature, 2011. Doi: https://doi.org/10.1038/478026a.

Vasconcelos, S. M. R. Integridade e conduta responsável na pesquisa: grandes desafios. Pesquisa FAPESP, n. 200, p. 58-59, 2012. Disponível em: https://revistapesquisa.fapesp. br/integridade-e-conduta-responsavel-na-pesquisa-grandesdesafios/. Acesso em: 20 fev. 2021.

Vlasschaert, C.; Topf, J. M.; Hiremath, S. Proliferation of papers and preprints during the coronavirus disease 2019 pandemic: progress or problems with peer review? Advances in Chronic Kidney Disease, v. 27, n. 5, p. 418-426. Doi: https://doi. org/10.1053/j.ackd.2020.08.003.

Wager, E. et al. Retractions: Guidance from the Committee on Publication Ethics (COPE). Maturitas, v. 64, n. 4, p. 201-203, 2009. Doi: https://doi.org/10.1016/j.maturitas.2009.09.018. 